\title{
Fish Fauna of the River Ravi and Its Some Tributaries with a New Record of Ailia puncata and Clupisoma naziri for Punjab State and Union Territory of Jammu and Kashmir, India
}

\author{
Dutta SPS* \\ Department of Environmental Sciences, University of Jammu, Jammu (180006), India \\ ${ }^{*}$ Corresponding author: Dr. Dutta SPS, Department of Environmental Sciences, University of Jammu, Jammu (180006), India; Email: duttasps@gmail.com
}

Received: March 03, 2021; Accepted: March 09, 2021; Published: March 16, 2021

\begin{abstract}
Fish fauna of the river Ravi and its some tributaries in Chamba district (H.P.) and from Shahpur (H.P.) to Gogga Mahal, Amritsar (Punjab) reported earlier and present survey from Ranjit Sagar dam to Kathour, Pathankot, Punjab, including Kathua district, has revealed the presence of 97 fish species belonging to 8 orders, 18 families and 53 genera. Among various orders, there is dominance of Cypriniformes ( 54 spp.) followed by Siluriformes (26 species), Percformes (9 species), Synbranchiformes (3 species), Osteoglossiformes (2 species) and Clupeiformes, Salmoniformes and Beloniformes (1 species, each). The list also includes a new record of Ailia punctata and Clupisoma naziri (reported earlier from Pakistan) for Punjab state and Union territory of Jammu and Kashmir. Salmo trutta fario noticed in Sewa River is also included in the present list. Like other Indian states, fish fauna is rapidly declining due to overfishing, fishing during monsoon breeding and illegal fishing methods (Dynamiting, electric shocking, poisoning etc.). Conservation status based on IUCN observations has also been discussed.
\end{abstract}

Keywords: Fish fauna, The River Ravi, New record of Ailia punctata and Clupisoma naziri

\section{Introduction}

Our knowledge of fish fauna of the river Ravi is by [1] from Chamba area of Himachal Pradesh; Kumar and Dua [2] from Punjab, [3] from Shahpur (H.P.) to Gogga Mahal, Amritsar, Punjab and [4] from Madhopur to Kathour (Pathankot). Earlier [5-12] surveyed fish fauna of some tributaries of the river Ravi in Kathua and Samba districts of Jammu. During the survey of river Ravi for the last ten years from Ranjit Sagar Dam to Kathour, Pathankot, some new records of fish have been observed and enlisted along with the earlier reports [1-4]. This work shall be helpful for the fishery biologists and fishery departments of Jammu, Punjab and Himachal Pradesh to undertake various fishery developmental programmes for the perennial river Ravi and its various tributaries.

\section{Topography of the Area and Methods}

The perennial Ravi River originates in the Himalayas in the Multhan tehsil of Kangra district, H.P., India. It is the smallest of the five Punjab Rivers that rises from glacier fields at an elevation of 14000 feet on the southern side of the Mid Himalayas. It flows through Bara Bhanghal, Bara Bansu and Chamba districts, H.P. It is joined by the Budhil River that rises in Lahul range of hills and is sourced from Manimahesh Kailash Peak and Manimahas Lake, at an elevation of 4080 meters above sea level. The second important tributary is the Nai or Dhona that rises at Kali Debi pass and flows $48 \mathrm{~km}$ before joining the river Ravi. Another major tributary that joins the Ravi River just below Bharmour, the old capital of Chamba, is the Seoul River. One more major tributary that joins the river Ravi near Bassohli, Kathua is Sewa River. The main river Ravi flows through the base of Dalhousie hill. Downstream it enters the Punjab plain near Madhopur and Pathankot. On its right bank, is the town of Lakhanpur and Kathua of Jammu Region. In Kathua district, the river Ravi is joined by Kathua Khad, Wajoo nullah, Tarna nullah, Jhandi nullah etc. Ujh River is another major tributary of the river Ravi in Kathua district. Its source is in the Kailash Mountains at an elevation of 14100 feet, close to the Bhaderwah Mountains in Doda district. It joins the river Ravi at Nainkot in Pakistan. Below Pathankot the river Ravi flows along the Indo Pak border for $80 \mathrm{kms}$ before entering Pakistan and joining the river Chenab. Basantar River, draining Samba district of Jammu region, joins the river Ravi in Pakistan.

Fishes collected by fishermen by using various methods were purchased, studied for colour patterns, photographed and fixed in $10 \%$ formaldehyde. For identification works of [13-21] have been consulted. For the systematic arrangement of the reported fish species, classification referred by [21] has been followed.

\section{Observations and Discussion}

Fish fauna of the river Ravi including earlier reports [1-4] is represented by 97 fish species belonging to 8 orders, 18 families and 
Dutta SPS (2021) Fish Fauna of the River Ravi and Its Some Tributaries with a New Record of Ailia puncata and Clupisoma naziri for Punjab State and Union Territory of Jammu and Kashmir, India

Table 1: Fish fauna of the river Ravi including the earlier reports by Sehgal (1974), Kumar and Dua (2012) and Moza (2014)

\begin{tabular}{|c|c|}
\hline & Conservation Status \\
\hline & IUCN (2020) \\
\hline \multicolumn{2}{|l|}{ Superclass: Gnathostomata } \\
\hline \multicolumn{2}{|l|}{ Class: Actinopterygii } \\
\hline \multicolumn{2}{|l|}{ Subclass: Neopterygii } \\
\hline \multicolumn{2}{|l|}{ Division: Teleostei } \\
\hline \multicolumn{2}{|l|}{ Subdivision: Osteoglossomorpha } \\
\hline \multicolumn{2}{|l|}{ Order: Osteoglossiformes } \\
\hline \multicolumn{2}{|l|}{ Suborder: Notopteroidei } \\
\hline \multicolumn{2}{|l|}{ Family: Notopteridae } \\
\hline \multicolumn{2}{|l|}{ Genus: Notopterus lacepede } \\
\hline 1.N.notopterus (Pallas) & LC \\
\hline Genus: Chitala Fowler & NT \\
\hline \multicolumn{2}{|l|}{ 2. C. chitala (Ham.-Buch.) } \\
\hline \multicolumn{2}{|l|}{ Sub division: Clupeomorpha } \\
\hline \multicolumn{2}{|l|}{ Order: Clupeiformes } \\
\hline \multicolumn{2}{|l|}{ Family: Clupeidae } \\
\hline \multicolumn{2}{|l|}{ Subfamily: Aliosinae } \\
\hline \multicolumn{2}{|l|}{ Genus: Gudusia Fowler } \\
\hline 3. G. chapra (Ham.-Buch.) & LC \\
\hline \multicolumn{2}{|l|}{ Subdivision: Euteleosostei } \\
\hline \multicolumn{2}{|l|}{ Superorder: Ostariophysi } \\
\hline \multicolumn{2}{|l|}{ Order: Cypriniformes } \\
\hline \multicolumn{2}{|l|}{ Family: Cyprinidae } \\
\hline \multicolumn{2}{|l|}{ Subfamily: Danioninae (= Rasborinae) } \\
\hline Genus: Salmophasia Swainson & \\
\hline 4. S. bacaiIa (Ham.-Buch.) & LC \\
\hline 5. S. phulo (Ham.-Buch.) & LC \\
\hline 6. S. punjabensis (Day) & $\mathrm{NE}$ \\
\hline Genus Securicula Gunther & \\
\hline 7. S. gora (Ham.-Buch.) & LC \\
\hline Genus: Asidoparia Heckel & \\
\hline 8. A morar (Ham.-Buch.) & LC \\
\hline Genus: Barilius Ham.-Buch. & \\
\hline 9. B. vagra vagra (Ham.-Buch.) & LC \\
\hline 10. B. barila (Ham.-Buch.) & LC \\
\hline 11. B. modestus Day & $\mathrm{NE}$ \\
\hline 12. B. radiolatus Gunther & $\mathrm{DD}$ \\
\hline 13. B. bendelisis (Ham.-Buch.) & LC \\
\hline Genus: Raiamas Jordan & \\
\hline 14. R. bola (Ham.-Buch.) & LC \\
\hline Genus: Chela (Ham.-Buch.) & \\
\hline 15. Chela cachius (Ham.-Buch.) & LC \\
\hline 16. Chela laubuca (Ham.-Buch.) & LC \\
\hline Genus: Esomus Swainson & \\
\hline 17. Esomus danricus (Ham.-Buch.) & LC \\
\hline Genus: Danio (Ham. Buch.) & \\
\hline 18. D. devario (Ham.-Buch.) & LC \\
\hline Genus: Rasbora Bleeker & \\
\hline 19. R. daniconius (Ham.-Buch.) & LC \\
\hline Genus: Amblypharyngodon Bleeker & \\
\hline 20. A. mola (Ham.-Buch.) & LC \\
\hline Subfamily: Cyprininae & \\
\hline Genus: Cyprinus Linnaeus & \\
\hline 21. C. carpio communis Linn. & $\mathrm{NE}$ \\
\hline 22. C. carpio specularis Lacepede & $\mathrm{NE}$ \\
\hline Genus: Tor Gray & \\
\hline
\end{tabular}

\begin{tabular}{|c|c|}
\hline 23. T. tor (Ham.-Buch.) & $\mathrm{DD}$ \\
\hline 24. T. putitora (Ham.-Buch.) & ENDN \\
\hline \multicolumn{2}{|l|}{ Genus: Osteobrama Heckel } \\
\hline 25. O. cotio cotio (Ham.-Buch.) & LC \\
\hline \multicolumn{2}{|l|}{ Genus: Puntius Ham.-Buch. } \\
\hline 26. P. sarana sarana (Ham.-Buch.) & $\mathrm{LC}$ \\
\hline 27. P. conchonius (Ham.-Buch.) & LC \\
\hline 28. P. terio (Ham.-Buch.) & LC \\
\hline 29. P. ticto (Ham.-Buch.) & LC \\
\hline 30. P. chola (Ham.-Buch.) & LC \\
\hline 31. P. sophore (Ham.-Buch.) & LC \\
\hline \multicolumn{2}{|l|}{ Genus: Cirrhinus Cuvier } \\
\hline 32. C. mirgala (Ham.-Buch.) & LC \\
\hline 33. C. reba (Ham.-Buch.) & LC \\
\hline \multicolumn{2}{|l|}{ Genus: Catla Valenciennes } \\
\hline 34. C. catla (Ham.-Buch.) & LC \\
\hline \multicolumn{2}{|l|}{ Genus: Labeo Cuvier } \\
\hline 35. L. bata (Ham.-Buch.) & LC \\
\hline 36. L. boga (Ham.-Buch.) & LC \\
\hline 37. L. calbasu (Ham.-Buch.) & LC \\
\hline 38. L. dero (Ham.-Buch.) & LC \\
\hline 39. L. dyocheilus (McClelland) & LC \\
\hline 40. L. gonius (Ham.-Buch.) & LC \\
\hline 41. L. pangusia (Ham.-Buch.) & NT \\
\hline 42. L. rohita (Ham.-Buch.) & LC \\
\hline 43. L. lippus ${ }^{* * *}$ Fowler & $\mathrm{DD}$ \\
\hline \multicolumn{2}{|c|}{ Subfamily: Oreininae (=Schizothoracinae) } \\
\hline \multicolumn{2}{|c|}{\begin{tabular}{|l|} 
Genus: Schizothorax Heckel \\
\end{tabular}} \\
\hline 44. S. richardsonii (Gray) & VULN \\
\hline \multicolumn{2}{|l|}{ Sub-family: Garrinae } \\
\hline \multicolumn{2}{|c|}{ Genus: Crossocheilus Kuhl and van Hasselt } \\
\hline 45. C. latius diplocheilus (Heckel) & $\mathrm{NE}$ \\
\hline 46. C. latius punjabensis* & $\mathrm{NE}$ \\
\hline \multicolumn{2}{|l|}{ Genus: Garra Hamilton - Buchanan } \\
\hline 47. G. gotyla gotyla (Gray) & LC \\
\hline 48. G. lamta (Ham.-Buch.) & LC \\
\hline \multicolumn{2}{|l|}{ Family: Balitoridae } \\
\hline \multicolumn{2}{|l|}{ Subfamily: Nemacheilinae } \\
\hline \multicolumn{2}{|l|}{ Genus: Nemacheilus Bleeker } \\
\hline 49. N. corica (Ham.-Buch.)* & LC \\
\hline \multicolumn{2}{|l|}{ Genus: Acanthocobitis Peters } \\
\hline 50. A. botia (Ham.-Buch.) & LC \\
\hline \multicolumn{2}{|l|}{ Genus: Schistura McClelland } \\
\hline 51. S. prashadi (Hora) & VULN \\
\hline 52. S. montanus (Mc Clelland.)* & $\mathrm{NE}$ \\
\hline 53. S. punjabensis (Hora) & $\mathrm{NE}$ \\
\hline \multicolumn{2}{|l|}{ Family: Cobitidiae } \\
\hline \multicolumn{2}{|l|}{ Subfamily: Botinae } \\
\hline \multicolumn{2}{|l|}{ Genus: Botia Gray } \\
\hline 54. Botia almorhae Gray & LC \\
\hline 55. Botia birdi Chaudhuri & $\mathrm{NE}$ \\
\hline 56. Botia lohachata Chaudhuri & $\mathrm{NE}$ \\
\hline \multicolumn{2}{|l|}{ Subfamily: Cobitinae } \\
\hline Genus: Lepidocephalus Bleeker & \\
\hline 57. L. guntea (Ham.-Buch.) & LC \\
\hline Order: Siluriformes & \\
\hline Family: Bagridae & \\
\hline Subfamily: Ritinae & \\
\hline Genus: Rita Bleeker & \\
\hline
\end{tabular}


Dutta SPS (2021) Fish Fauna of the River Ravi and Its Some Tributaries with a New Record of Ailia puncata and Clupisoma naziri for Punjab State and Union Territory of Jammu and Kashmir, India

\begin{tabular}{|c|c|}
\hline 58. R. rita (Ham. Buch.) & LC \\
\hline \multicolumn{2}{|l|}{ Subfamily: Bagrinae: Genus: Mystus Scopoli } \\
\hline 59. M. bleekeri (Day) & LC \\
\hline 60. M. cavasius (Ham.-Buch.) & LC \\
\hline 61. M. vittatus (Bloch.) & LC \\
\hline 62. M. tengara (Ham.-Buch.) & LC \\
\hline \multicolumn{2}{|l|}{ Genus: Aorichthys Wu } \\
\hline 63. A. seenghala (Sykes) & LC \\
\hline 64. A. aor (Ham.-Buch.)** & LC \\
\hline \multicolumn{2}{|l|}{ Family: Siluridae } \\
\hline \multicolumn{2}{|l|}{ Genus: Ompok Lacepede } \\
\hline 65. O. pabda (Ham.-Buch.) & NT \\
\hline \multicolumn{2}{|l|}{ Genus: Wallago Bleeker } \\
\hline 66. W. attu (Bloch. \& Schn.) & VULN \\
\hline \multicolumn{2}{|l|}{ Family: Schilbidae } \\
\hline \multicolumn{2}{|l|}{ Subfamily: Ailinae } \\
\hline \multicolumn{2}{|l|}{ Genus: Ailia Gray } \\
\hline 67. A punctata (Day) & DD \\
\hline \multicolumn{2}{|l|}{ Sub family: Schilbinae } \\
\hline \multicolumn{2}{|l|}{ Genus: Neotropius Kulkarni } \\
\hline 68. N. atherinoides (Bloch.) & LC \\
\hline \multicolumn{2}{|l|}{ Genus: Clupisoma Swainson } \\
\hline 69. C. garua (Ham.-Buch.) & LC \\
\hline 70. C. nazri Mirza and Awan & $\mathrm{NE}$ \\
\hline \multicolumn{2}{|l|}{ Genus: Eutropiichthys Bleeker } \\
\hline 71. E. murius (Ham.-Buch.) & LC \\
\hline 72. E. vacha (Ham.-Buch.) & LC \\
\hline \multicolumn{2}{|l|}{ Family: Amblycipitidae } \\
\hline \multicolumn{2}{|l|}{ Genus: Amblyceps Blyth } \\
\hline 73. A mangois (Ham.-Buch.) & LC \\
\hline \multicolumn{2}{|l|}{ Family: Sisoridae } \\
\hline \multicolumn{2}{|l|}{ Genus: Bagarius Bleeker } \\
\hline 74. B. bagarius (Ham.-Buch.) & NT \\
\hline \multicolumn{2}{|l|}{ Genus: Gagata Bleeker } \\
\hline 75. G. cenia (Ham.-Buch.) & LC \\
\hline \multicolumn{2}{|l|}{ Genus: Glyptosternum McClelland } \\
\hline 76. G. reticulatum McClelland* & $\mathrm{NE}$ \\
\hline \multicolumn{2}{|l|}{ Genus: Glyptothorax Blyth } \\
\hline 77. G. cavia (Ham.-Buch.) & LC \\
\hline 78. G. conirostre conirostre( Steindachner) ${ }^{*}$ & DD \\
\hline 79. G. pectinopterus (McClelland)* & LC \\
\hline 80. G. stoliczkae (Steindachner) & LC \\
\hline 81. G. telchitta (Ham.-Buch.) & LC \\
\hline Family: Clariidae & \\
\hline Sub-Family: Heteropneustinae & \\
\hline Genus: Heteropneustes Muller & \\
\hline 82. H. fossilis (Bloch.) & LC \\
\hline Sub-Family: Clariinae & \\
\hline Genus: Clarius Scopoli & \\
\hline 83. C. batrachus (Linneaus) & LC \\
\hline Superorder: Protacanthopterygii & \\
\hline Order: Salmoniformes & \\
\hline Family: Salmonidae & \\
\hline Genus: Salmo Linnaeus & \\
\hline 84. S. trutta fario Linn. & $\mathrm{NE}$ \\
\hline Superorder: Acanthopterygii & \\
\hline Order: Beloniformes & \\
\hline Suborder: Belonoidei (=Exocoetoidei) & \\
\hline Family: Belonidae Genus: Xenentodon Regan & \\
\hline
\end{tabular}

\begin{tabular}{|l|c|}
\hline 85. X. cancila (Ham.-Buch.) & LC \\
\hline Order: Synbranchiformes & \\
\hline Suborder: Mastacembeloidei & \\
\hline Family: Mastacembelidae & \\
\hline Subfamily: Mastacembelinae & \\
\hline Genus: Macroganthus Lacepede & LC \\
\hline 86. M. aral (Bloch and Schn.) & LC \\
\hline 87. M. pancalus (Ham.-Buch.) & \\
\hline Genus: Mastacembelus Scopoli & LC \\
\hline 88. M. armatus (Lac.) & \\
\hline Order: Perciformes & \\
\hline Suborder: Percoidei & \\
\hline Family: Chandidae (Ambassidae) & \\
\hline Genus: Chanda (Ham.-Buch.) & \\
\hline 89. C. nama Ham.-Buch. & \\
\hline Genus: Parambassis Bleeker & LC \\
\hline 90. P. baculis (Ham.-Buch) & \\
\hline 91. P. ranga (Ham.-Buch.) & LC \\
\hline Family: Nandidae & LC \\
\hline Subfamily: Nandinae & \\
\hline Genus: Nandus Valenciennes & LC \\
\hline 92. N. nandus (Ham.-Buch.) & LC \\
\hline Sub order: Gobioidei & LC \\
\hline Family: Gobiidae & \\
\hline Genus: Glossogobius Gill & \\
\hline 93. G. giuris (Ham.-Buch.) & \\
\hline Suborder: Channoidei & \\
\hline Family: Channidae & \\
\hline Genus: Channa Scopoli & \\
\hline 94. C. marulius (Ham.-Buch.) & \\
\hline 95. C. orientalis Bloch\&Schneider & \\
\hline 96. C. punctatus (Bloch.) & \\
\hline 97. C. striatus (Bloch.) & \\
\hline
\end{tabular}

${ }^{*}$ Reported by Sehgal (1974) and not seen during present study

${ }^{*}$ Reported by Moza (2014) and not seen during present study

$* * *$ Reported by Kumar and Dua (2012) and not seen during present study

LC $=$ Least Concern

ENDN $=$ Endangered

NT $=$ Near Threatened

$\mathrm{DD}=$ Data Deficient

$\mathrm{NE}=$ Not Evaluated

VULN $=$ Vulnerable

52 genera (Table 1). Ailia punctata reported earlier [22] from Pakistan segment of the river Ravi and Clupisoma naziri distributed in the rivers of Pakistan are the new records for Punjab and Jammu and Kashmir. Fish analysis in the Indian segment of the river Ravi has shown the dominance of Cypriniformes (54 spp.) followed by Siluriformes (26 species), Percformes (9 species), Synbranchiformes (3 species), Osteoglossiformes (2 species) and Clupeiformes, Salmoniformes and Beloniformes (1 species, each). In the river Ravi from the Ranjit Sagar dam to Kathour (Pathankot), including Kathua area, is more diversified (Table 1) in comparison to 16 fish species viz. Barilius bendelisis, $B$. vagra, Puntius conchonius, Labeo dero, Cyprinus carpio specularis, $C$. communis, Garra gotyla, Schizothorax richardsonii, Crossocheilus latius punjabensis, Noemacheilus corica, N. montanus, Lepidocephalus guntea, Glyptosternum reticulatum, Glytothorax conirostres, G. pectinopterus and G. stoliczkae belonging to 2 orders, 3 families and 11 genera reported by [1] from Chamba area, H.P., drained by the river Ravi. 
[2] enlisted 38 fish species viz. Notopterus notopterus, Catla catla, Cirrhinus mrigala, Cirrhinus reba, Cyprinus carpio communis, Labeo bata, L. calbasu, L. dero, L. lippus, L. rohita, Osteobrama cotio cotio, Puntius sarana sarana, P. terio, Salmostoma bacaila, Parluciosoma daniconius, Schizothorax richardsonii, Tor tor, Lepidocephalus guntea, Aorichthys aor, A. seenghala, Mystus bleekeri, M. cavasius, M. vittatus, Rita rita, Wallago attu, Clupisoma garua, Eutropiichthys murius, E. vacha, Bagarius bagarius, Clarias batrachus, Xenentodon cancila, Colisa fasciatus, Channa marulius, C. punctatus, C. striatus, Macrognathus aral, $M$. pancalus and Mastacembelus armatus belonging to 5 orders, 12 families and 25 genera from the Indian segment of the river Ravi in Punjab.

Present record of fish diversity in the river Ravi is higher than the earlier reports of 31 fish species viz. Notopterus notopterus, N. chitala, Chela bacaila, Tor putitora, Puntius sarana, Catla catla, Cirrhinus mrigala, C. reba, Labeo dyocheilus, L. gonius, L. rohita, L. calbasu, L. dero, L. bata, Cyprinus carpio specularis, Schizothorax richardsonii, Mystus aor, M. seenghala, M. tengara, Rita rita, Bagarius bagarius, Wallago attu, Eutropiichthys vacha, Clupisoma garua, Heteropneustes fossilis, Clarias batrachus, Xenentodon cancila, Mastacembelus armatus, M. pancalus, Channa marulius and Channa punctaus belonging to 5 orders, 9 families and 20 genera enlisted by Moza [3] in the river Ravi from Shahpur (H.P) to Goga Mahal, Amritsar, Punjab.

Fish diversity in the Indian segment of river Ravi is even higher in comparison to the earlier reports of 75 fish species (Notopterus notopterus, N. chitala, Gudusia chapra, Aspidoparia morar, Amblypharyngodon mola, Barilius bendelisis, B. modestus, B. vagra, Cirrhinus mrigala, C. reba, Cyprinus carpio, Carasius auratus, Crossocheilus diplocheilus, Chela cachius, Chela labuca, Esomus danricus, Gibleon catla, Garra gotyla, L. dyocheilus pakistanicus, Labeo rohita, L. gonius, L. calbasu, L. dero, Osteobrama cotio, Puntius punjabensis, P. sophore, P. ticto, P. chola, P. conchonius, Rasbora daniconius, Salmophasia punjabensis, S. bacaila, Securicula gora, Systomus sarana, Tor macrolepis, Nemacheilus sp., Botia lohachita, Ailia punctatus, Ailia coilia, Clupisoma garua, Eutropiichthys vacha, Gagata cenia, Heteropneustes fossilis, Mystus bleekeri, M. cavasius, M. vitatus, M. tengra, Ompok bimaculatus, Pseudoeutropis atherinoides, Wallago attu, Rita rita, Sisor pakistanicus, Sperata sarwari (Mystus seenghala and M. aor), Glyptothorax stocki, G. punjabensis, Xenetodon cancila, Macrognathus aculeatus, Macrognathus pancalus, Mastacembelus armatus, Monopterus cuchia, Colissa fasciata, Colissa latia, Chanda nama, Parambassius baculis, P. ranga, Glossogobius giuris, Nandus nandus, Oreochromis aureus, O. mosambicus, O. niloticus, Channa marulius, C. punctatus, Channa striatus, C. gachua and Sicamugal cascasia) enlisted from Pakistan segment of the river Ravi by Ahmad* (1943, 49 fish species), Mirza ${ }^{\star}$ (1970, 65 fish species), Zahoor and $\operatorname{Mirza}^{\star}$ (2002, 49 fish species) and [22] (2018, 38 fish species). Recent study of the river Ravi in Pakistan segment by [22] has revealed the presence of 38 fish species (Aspidoparia morar, Barilius bendelisis, $B$. modestus, B. vagra, Cirrhinus mrigala, C. reba, Cyprinus carpio, Carasius auratus, Gibleon catla, Labeo rohita, L. gonius, L. calbasu, L. dyocheilus pakistanicus, Puntius punjabensis, P. sophore, P. ticto, Salmophasia punjabensis, Securicula gora, Clupisoma garua, Eutropiichthys vacha, Heteropneustes fossilis, Wallago attu, Sperata sarwari, Chanda nama,
Colissa fasciata, Colissa latia Channa marulius, C. punctatus, Channa striatus, C. gachua, Oreochromis aureaus, O. mosambicus, O. niloticus, Parambassius baculis, P. ranga Mastacembelus armatus, Notopterus chitala and $N$. notopterus) belonging to 22 genera, 10 families and 8 orders. This fish decline during last few decades has been attributed to degrading water quality caused by increased anthropogenic activities and many fold decline in water flow in the rivers after Indus water Basin treaty with India.

\section{${ }^{\star}$ Cited from [22].}

Rich diversity in the river Ravi downstream Ranjit Sagar Dam to Kathour is due to reduced water flow, shallowness and penetration of light upto the bottom, presence of pools supporting a rich diversity and density of fish food organisms viz. macrophytes, algae, benthos, zooplankton, fish, etc. and absence of any pollution. Moreover, there is an upstream fish migration, even from Pakistan, during summer and monsoon. During monsoon, there is downstream fish drift from upper catchment along with floods. It is during summer and monsoon when a rich diversity and density of fish in the river Ravi has been noticed. Moreover, a large number of tributaries join the river Ravi at various places and add to rich fish diversity.

Study of fish fauna of various tributaries of the river Ravi in Kathua district started with a survey by [5] who enlisted 12 fish species belonging to 4 orders, 6 families and 11 genera from Kathua Khad and 3 fish species viz. Barilus vagra, Tor putitora and Channa punctatus from Ujh River. [8] noticed 27 fish species belonging to 4 orders, 8 families and 20 genera from Ujh River; 16 fish species belonging to 2 orders, 4 families and 12 genera from Tarnah nullah and total absence of fish from seasonal Kathua Khad, Rathore and [11] noticed 42 fish species belonging to 5 orders, 10 families and 27 genera from river Ujh. [12] reported 64 fish species belonging to 7 orders, 17 families and 42 genera from Wajoo nullah and its tributaries. Dutta and Gupta (unpublished) noticed 8 fish species viz. Schizothorax richardsonii, Barilius vagra vagra, B. bendelisis, Crossocheilus latius diplocheilus, Tor putitora, Cirrhinus reba, Salmo trutta fario and Glyptothorax stoliczkae from Sewa river, an important tributary of the river Ravi in Bassohli, Kathua.

[7] surveyed fish fauna of river Basantar, an important tributary of the river Ravi, in Samba district of Jammu, and enlisted 59 fish species belonging to 6 orders, 15 families and 41 genera. Sharma and Dutta $\neq \pi$ documented 35 fish species belonging to 5 orders, 10 families and 25 genera, with maximum diversity and density during monsoon floods, in river Basantar.

The [23] redlist showed that, among 97 fish species in the river Ravi, only Tor putitora is endangered, Chitala chitala, Labeo pangusia, Ompok pabda and Bagarius bagarius are near threatened; Schizothorax richardsonii, Schistura prashadi and Wallago attu are vulnerable; Tor tor, Barilius radiolatus, Labeo lippus, Ailia punctata and Glyptothorax conirostrae conirostrae are data deficient; Barilius modestus, Schistura punjabensis, Schistura mountanous, Salmophasia punjabensis, Crossocheilus latius punjabensis, Crossocheilus latius diplocheilus, Cyprinus carpio communis, Cyprinus carpio specularis, Botia birdi, Botia lohachata, Salmo trutta fario, Clupisoma naziri and Glyptosternum reticulatum are not evaluated and remaining fishes are in the least concern category. 
An overall study has revealed a decline in fish diversity and density in the river Ravi and its tributaries. This needs immediate attention by the fishery departments of Himachal Pradesh and Punjab states and Jammu \& Kashmir union territory. Illegal destructive methods of fishing like dynamiting, poisoning and diversion of water for catching fish should be checked. Total ban on fishing during summer and monsoon spawning migration should be implemented. In the tributaries, Juveniles need protection when the water level goes low in summer months. To protect them from poaching certain artificial pools need to be created. Some areas along the river Ravi and its tributaries should be declared as protected and reserved waters. Cultural possibilities of native and other fish species need exploration in different segments of the river Ravi and its tributaries.

\section{Acknowledgements}

This paper is a part of the Emeritus Fellowship Project sanctioned by UGC, New Delhi, and is gratefully acknowledged. Thanks are due to HOD, Environmental Sciences, University of Jammu, Jammu, for providing necessary laboratory facilities in the department.

\section{References}

1. Sehgal KL (1974) Fisheries survey of Himachal Pradesh and some adjacent areas with special reference to trout, mahseer and allied species. J Bombay Nat Hist Soc 70: $458-474$.

2. Kumar A, Dua A (2012) Fish diversity of River Ravi in Indian region. Eco Env and Cons 18: 861-864.

3. Moza U (2014) River Ravi: Ecology and Fishery. Directorate of knowledge management in agriculture. Indian Council of Agricultural Research, New Delhi 110012: 101.

4. Dutta SPS (2015) Fish fauna of the river Ravi with a new record of (Day) for Jammu and Kashmir and Punjab states and Gudusia Chapra (Ham.-Buch.) for Jammu and Kashmir state. 26 All India Congress of Zoology and International Seminar on Innovation in Animal Science for Food security, Health security and Livelihood. Organised by Baba Saheb Bhimrao Ambedkar Central University, Lucknow. $29^{\text {th }}-31^{\text {st }}$ October, 2015.

5. Joshi CS, Sehgal KL, Sunder S (1978) Observations on the fishery resources of hill streams of Jammu province with special reference to mahseer and other commercially important species. Indian J Fish 25: 197-206.

6. Guglani HK (2000) Survey and systematic analysis of fish fauna of Jammu region. $\mathrm{PhD}$. Thesis. University of Jammu, Jammu.
7. Dutta SPS, Kour H, Bali JPS, Sharma LD (2001) Hydrobiological studies on river Basantar, Samba, Jammu, jammu and Kashmir. J. Aquatic Biol 16: 41-44.

8. Dutta SPS, Gupta SC, Rathore V, Sharma A (2006) Fish fauna of some tributaries of the river Ravi; District Kathua, J\&K state, In: Trends in Biodiversity and Aquaculture. Edited by Wanganeo, A. and Langer, R.K. Daya Publishing House, New Delhi: 443452 .

9. Dutta SPS, Kour H (2005) Fish fauna of Kathua District, Jammu region. In Proceedings National Seminar: New trends in Fishery Development in India, Punjab University, Chandigarh Feb 16-18: 233-240.

10. Sharma A, Dutta SPS (2012) Present and past status of fish fauna of river Basantar, an important tributary of the river Ravi in Samba district, Jammu (J\&K). J Applied and Natural Resources 4: 123-126.

11. Rathore V, Dutta SPS (2015) Fish fauna of river Ujh, an important tributary of the river Ravi, District Kathua, Jammu. Environment Conservation J 16: 81-86.

12. Dutta SPS (2016) Fish fauna of Wajoo nullah, an important tributary of river Ravi in Kathua district, Jammu region, Jammu and Kashmir state, India. JANS 8: 1087-1089.

13. Hamilton BF (1822) An account of the fishes found in the river Ganga and its tributaries. Edinburg and London.

14. Misra KS (1962) An aid to the identification of the common commercial fishes of India and Pakistan. Rec Indian Mus 57: 1-320.

15. Malhotra YR, Jyoti MK (1971) An identification of fishes found in Jammu. J Assam Sci Soc 14: 184-192.

16. Dutta SPS, Malhotra YR (1984) An upto date checklist and a key to the identification of fishes of Jammu. Jammu University Review (Sciences) J 2: 65-92.

17. Johal MS, Tandon KK (1979) Monograph on the fishes of re-organised Punjab. $P b$ Fish Bull 3: 1-44.

18. Johal MS, Tandon KK (1980) Monograph on the fishes of re-organised Punjab. $P b$ Fish Bull 4: 39-51.

19. Talwar PK, Jhingram AG (1991) Inland fishes of India and adjacent countries, Oxford and IBH publishing Co. Pvt. Ltd., New Delhi, Vols. I and II.

20. Day F (1994) The fishes of India, being a natural history of the fishes known to inhabit seas and freshwaters of India, Burma and Ceylon, Fourth India Reprint Vol I and II, Jagmandir Book Agency, New Delhi.

21. Jayaram KC (2013) The freshwater fishes of the Indian region, Narendra Publishing House, Delhi.

22. Pervaiz K, Mirza ZS, Siddiqui S, Waheed KN, Hayat S, et al. (2018) Studies on the fish biodiversity of river Ravi in Punjab, Pakistan. J Entomology and Zoology Studies 6: 1442-1448.

23. IUCN (2020) The IUCN Redlist of threatened species. Version 2020-2. www. iucnredlist.org. 